\title{
Risk Factors of Hypertension in High School Students: Multilevel Evidence of The Contextual Effect of School
}

\author{
Mayasari Kurnianingsih'), Yulia Lanti Retno Dewi'), \\ Eti Poncorini Pamungkasari ${ }^{2}$ \\ ${ }^{1)}$ Masters Program in Public Health, Universitas Sebelas Maret \\ ${ }^{2)}$ Faculty of Medicine, Universitas Sebelas Maret
}

\begin{abstract}
Background: In 2025, it is projected that $29 \%$ of the world's citizens will suffer from hypertension. Hypertension does not only occur in adults but in adolescents. The prevalence of Indonesian hypertension is relatively high at $34.1 \%$. Hypertension if not treated immediately can cause death. This study aimed to analyze risk factors of hypertension in high school students.

Subjects and Method: This was a cross sectional study conducted in Bantul, Yogyakarta, from April to May 2019. A sample of 200 adolescents aged 15-19 years was selected by probability sampling. The dependent variable was hypertension. The independent variables were gender, genetic history, obesity, dietary pattern, sleep duration, stress, and money pocket. The data on hypertension were collected using sphygmomanometer. BMI was measured by microtoise and weight scale. Data on stress were measured by perceived stress scale (PSS). The other variables were collected by questionnaire. The data were analyzed by multilevel logistic regression.

Results: The risk of hypertension increased with male gender $(b=1.87 ; 95 \% \mathrm{CI}=0.38$ to $3.36 ; \mathrm{p}=$ $0.014)$, genetic history $(b=1.93 ; 95 \% \mathrm{CI}=0.48$ to $3.39 ; \mathrm{p}=0.009)$, obesity $(b=2.15 ; 95 \% \mathrm{CI}=0.76$ to $3.55 ; \mathrm{p}=0.002)$, poor dietary pattern $(\mathrm{b}=1.54 \mathrm{CI} 95 \%=0.97$ to $2.99 ; \mathrm{p}=0.036)$, sleep duration $<8$ hours/day $(b=2.28 ; 95 \% \mathrm{CI}=0.63$ to $3.93 ; \mathrm{p}=0.007)$, high stress $(\mathrm{b}=3.52 ; 95 \% \mathrm{CI}=1.64$ to $5.39 ; \mathrm{p}<0.001)$, and high money pocket $(\mathrm{b}=2.00 ; 95 \% \mathrm{CI}=0.45$ to $3.56 ; \mathrm{p}=0.011)$. School had contextual effect on hypertension with ICC $=22.47 \%$.

Conclusions: The risk of hypertension increased with male gender, genetic history, obesity, poor dietary pattern, sleep duration $<8$ hours/day, high stress, and high money pocket. School has contextual effect on hypertension.
\end{abstract}

Keywords: hypertension, adolescence, diet, stress, duration of sleep, socio-economic

\section{Correspondence:}

Mayasari Kurnianingsih. Masters Program in Public Health, Universitas Sebelas Maret. Jl. Ir. Sutami 36A, Surakarta 57126, Central Java. Email: mayyasarikurnia@gmail.com. Mobile: +6285729990090.

\section{BACKGROUND}

The World Health Organization (WHO) estimates that the number of people with hypertension will continue to increase along with the increasing population. In the upcoming 2025, it is projected that around $29 \%$ of the world's citizens experience hypertension (World Health Organization, 2013).

Nationally, the prevalence of hypertension in adolescents aged 15-17 years is 5.3\% (Baseline Health Research, 2013). The
Provincial Health Office of the Special Region of Yogyakarta reported the incidence of hypertension was $35.8 \%$ higher than the national prevalence rate and became the top 5 provinces with the highest population experiencing hypertension. Based on 10 patterns of outpatient disease and hospitalization for all age groups in Bantul Regency, primary hypertension ranks second with the number of sufferers as many as 37,692 cases (Yogyakarta Health Office, 2017). 
Journal of Epidemiology and Public Health (2019), 4(4): 259-269

https://doi.org/10.26911/jepublichealth.2019.04.04.01

Teenagers are the age group that is vulnerable to changes in the era of globalization. In terms of cognitive and psychosocial development, adolescents who are immature will be easily affected by the environment. Fluctuations in feelings of adolescents who have high curiosity will encourage adolescents to dig up information and imitate various role models so that they can influence patterns of disease, one of which is hypertension (Arisman, 2009).

From the results of blood pressure measurements in adolescents in 2 high schools with a background in rural and urban areas in Bantul, in January 2019, there were 23 out of 256 results or $8.9 \%$ of students had hypertension. The author conducted a preliminary study by interviewing several respondents who were known to have hypertension in January 2019 and the results obtained were all respondents did not know that they had hypertension and felt that they were in good health. This is consistent with the study of Aglony et al., Which showed that nearly $75 \%$ of cases of hypertension and $90 \%$ of pre-hypertensive cases in adolescents were undiagnosed cases (Aglony et al., 2009). Adolescents aged 15-19 are an age group that is often considered healthy, whereas in reality there are many risks that threaten. Hypertension is often given the title The Sillent Killer because this disease is a hidden killer (WHO, 2013).

Hypertension that occurs in adolescents is influenced by several risk factors (biopsychosocial economics) both from internal including biological, psychological and external factors including social and economic. Factors that cause biological hypertension are excessive weight or obesity. The prevalence of obesity in Indonesia in 2013 was $14.8 \%$ with indicators of obesity in body mass index (BMI) (Riskesdas, 2013). Another biological factor is a diet that affects hypertension, namely not doing a good diet by consuming unhealthy foods (Yusrizal et al., 2017). 77.3\% of people in Indonesia aged $\geq 10$ years consume flavoring ingredients (Riskesdas, 2013).

Gender factors can also influence hypertension. Family history is also a factor that affects hypertension in adolescents (Yusrizal et al., 2017). 6\% of adolescent boys and $4.7 \%$ of female adolescents in Indonesia experience hypertension (Riskesdas, 2013). Individuals with a family history of hypertension can increase the odds 2 times higher than those who do not have hypertension (Loh et al., 2013; Manimunda et al., 2011).

Psychological factors that can affect increased blood pressure or hypertension are psychological disorders (stress, depression, and anxiety) (Yanes and Reckelhoff, 2011). The higher the stress level, the higher the risk of developing hypertension (Istyanto et al., 2019). Huang et al. explain that stress increases about $9.1 \%$ of the risk of hypertension (Huang et al., 2016). High stress levels will also interfere with the quality of sleep (Istyanto et al., 2019). Sleep disturbances, staying up late, and poor sleep quality affect 1.84 times the risk of hypertension compared to those who have good sleep quality (Bansil et al., 2011).

Social factors that can influence the incidence of hypertension are one of the external environments for individual disease manifestations. The surrounding environment includes conditions that affect hypertension or adolescent school contextual factors such as the quality of teaching and learning activities (KBM), school facilities especially the school health unit (UKS), and the school canteen environment. Preventive behavior should be applied as a teenager so that it does not worsen the situation (Puspita et al., 2017). Based on the description above the authors 
were interested in conducting a study on "the contextual influence of schools and economic biopsychosocial factors on the incidence of hypertension in adolescents aged 15-19 years".

\section{SUBJECTS AND METHOD \\ 1. Study Design}

This study used a cross sectional design. It was conducted in Bantul Regency in April May 2019. It was conducted in 25 high schools / vocational schools in Bantul Regency.

\section{Population and samples}

The target population of this study were all adolescents aged 15-19 years in high school / vocational high school in Bantul Regency in April - May 2019. The sampling was done using probability sampling techniques to select adolescents and schools in Bantul region. The subjects used were 200 subjects from 8 subjects in each level 2 unit (school).

\section{Study Variables}

The dependent variable in this study was hypertension in adolescents aged 15-19 years. The independent variables included: gender, genetic history, obesity, diet, sleep duration, stress level, economic level (pocket money), and level 2 school.

\section{Operational Definition of Variables}

Gender. Gender was the gender difference in subjects that can affect variables, namely male and female gender.

Genetic history. Genetic history was a history of illness experienced by the family consisting of father, mother, grandfather, grandmother, and siblings who suffer from hypertension.

Obesity. Obesity was a disorder or condition that was characterized by excessive accumulation of body fat tissue.

Diet. A diet was a dietary arrangement or consumption that is prohibited, restricted, or permitted by a certain amount by patients with hypertension or for someone who wanted to avoid hypertension.

Sleeping duration. Sleep duration was the duration of sleep in 24 hours based on the frequency of sleeping for the past 7 days.

Stress. The level of stress was a condition experienced by someone because of the demands from outside that were considered harmful to the body.

Economical status. Economic level was the amount of pocket money received by the subject per month obtained from father or mother and or both.

Hypertension. Hypertension was an abnormal increase in blood pressure in arteries with a measure of systolic blood pressure $\geq 140 \mathrm{mmHg}$ and / or diastolic $\geq 90$ mmHg. The measurement scale was continous.

\section{Data Analysis}

Univariate analysis aimed to explain each variable, namely the independent and dependent variables. Bivariate analysis was conducted to determine the effect of the dependent and independent variables using the chi-square test. Multivariate analysis employed logistic regression through a multilevel approach as indicated by intra class correlation (ICC) values.

\section{Research Ethics}

The research ethics included informed consent, anonymity, confidentiality, and ethical clearance. Ethical clearance was obtained from Dr. Moewardi Hospital, Surakarta, Central Java, with number: 454 / IV / HERC / 2019.

\section{RESULTS}

\section{Sample characteristics}

The subjects in this study were 200 adolescents aged 15-19 years. The frequency distribution of the characteristics of the subjects is described in table 1 . Table 1 
Journal of Epidemiology and Public Health (2019), 4(4): 259-269

https://doi.org/10.26911/jepublichealth.2019.04.04.01

showed that most of the subjects were female with 165 subjects (82.5\%).

\section{Univariate Analysis}

Table 1 showed the results of univariate analysis. Table 1 showed the majority of female subjects amounting to 165 subjects (82.5\%), no genetic history of 157 subjects

\section{Table 1. Univariate Analysis}

\begin{tabular}{|c|c|c|}
\hline Variable & $\mathbf{n}$ & $\%$ \\
\hline \multicolumn{3}{|l|}{ Hypertension } \\
\hline Hypertension & 27 & $13 \cdot 5$ \\
\hline No hypertension & 173 & 86.5 \\
\hline \multicolumn{3}{|l|}{ Gender } \\
\hline Male & 35 & 17.5 \\
\hline Female & 165 & 82.5 \\
\hline \multicolumn{3}{|l|}{ History of genetic } \\
\hline Yes & 43 & 21.5 \\
\hline No & 157 & 78.5 \\
\hline \multicolumn{3}{|l|}{ Obese } \\
\hline Yes $\left(\mathrm{BMI} \geq 25 \mathrm{~kg} / \mathrm{m}^{2}\right)$ & 41 & 20.5 \\
\hline No $\left(\mathrm{BMI}<25.0 \mathrm{~kg} / \mathrm{m}^{2}\right)$ & 159 & 79.5 \\
\hline \multicolumn{3}{|l|}{ Diet } \\
\hline Diet causing hypertension (score $\geq 8$ ) & 40 & 20.0 \\
\hline Diet not causing hypertension (score $<8$ ) & 160 & 80.0 \\
\hline \multicolumn{3}{|l|}{ Sleeping duration } \\
\hline Lacking ( $<8$ hours) & 49 & 24.5 \\
\hline $\operatorname{Enough}(\geq 8$ hours $)$ & 151 & $75 \cdot 5$ \\
\hline \multicolumn{3}{|l|}{ Stress Level } \\
\hline Stress (score $\geq 13$ ) & 23 & 11.5 \\
\hline Not stress (score < 13) & 177 & 88.5 \\
\hline \multicolumn{3}{|l|}{ Pocket money } \\
\hline Adequate (< Rp 350,o0o) & 165 & 82.5 \\
\hline $\operatorname{High}(\geq \operatorname{Rp} 350,000)$ & 35 & 17.5 \\
\hline
\end{tabular}

\section{Bivariate analysis}

Table 2 showed the results of bivariate analysis. Table 2 showed that male $(\mathrm{OR}=3.48$; 95\% $\mathrm{CI}=1.26$ to $9.11 ; \mathrm{p}<0.001)$, family history of hypertension $(\mathrm{OR}=3.66 ; 95 \%$ $\mathrm{CI}=1.40$ to $9.29 ; \mathrm{p}<0.001)$, obesity (OR= $4.80 ; 95 \% \mathrm{CI}=1.84$ to $12.29 ; \mathrm{p}<0.001)$, poor dietary pattern $(\mathrm{OR}=2.80$ to 7.21 ; 95\% $\mathrm{CI}=1.03 ; \mathrm{p}<0.001)$, sleep duration $<8$ hours/day $(\mathrm{OR}=4.24 ; 95 \% \mathrm{CI}=1.66$ to 10.71; $\mathrm{p}<0.001)$, high stress $(\mathrm{OR}=5.67$; $95 \% \mathrm{CI}=1.86$ to $16.36 ; \mathrm{p}<0.001)$, and high pocket money $(\mathrm{OR}=2.82 ; 95 \% \mathrm{CI}=0.99$ to 7.47 ; $<$ 0.001) increased the risk of hypertension among adolescents.
(78.5), not obese amounting to 159 subjects (79.5\%), diets that did not cause hypertension were 160 subjects (80.0\%), enough sleep duration was 151 (75.5\%), and no stress amounted to 177 subjects (88.5\%), and economic levels (pocket money) were enough amounting to 165 subjects (82.5\%). 35

\section{Multilevel Analysis}

Table 3 showed the results of multivariate analysis. Table 3 showed that male subjects $(b=1.87 ; 95 \% \mathrm{CI}=0.38$ to $3.36 ; \mathrm{p}=0.014)$, had a genetic history $(b=1.93 ; 95 \% \mathrm{CI}=$ 0.48 to $3.39 ; p=0.009)$, obesity $(b=2.15$; $95 \% \mathrm{CI}=0.76$ to $3.55 ; \mathrm{p}=0.002$ ), poor dietary pattern $(\mathrm{b}=1.54 ; 95 \% \mathrm{CI}=0.09$ to 2.99; $\mathrm{p}=0.036)$, sleep duration $<8$ years $(b=2.28 ; 95 \% \mathrm{CI}=0.63$ to $3.93 ; \mathrm{p}=0.007)$, high stress $(b=3.52 ; 95 \% \mathrm{CI}=1.64$ to 5.39 ; $\mathrm{p}<0.001$ ), and high economic level (pocket money) $(\mathrm{b}=2.00 ; 95 \% \mathrm{CI}=0.45$ to $3.56 ; \mathrm{p}$ $=0.011$ ) had a statistically significant effect 
on hypertension in adolescents aged 15-19 years.

Analysis at the school level shows that ICC $=22.47 \%$, this indicates that variations in hypertension in adolescents aged 15-19 years $22.47 \%$ were determined by variables at the school level. The ICC value in this study is greater than the benchmark rule of thumb 8-10\%, then the school's contextual influence was very important to note.

Table 2. Bivariate Analysis

\begin{tabular}{|c|c|c|c|c|c|c|c|c|}
\hline \multirow{3}{*}{ Independent Variables } & \multicolumn{4}{|c|}{ Hypertension } & \multirow{3}{*}{ OR } & \multirow{2}{*}{\multicolumn{2}{|c|}{$95 \%$ CI }} & \multirow{3}{*}{$\mathbf{p}$} \\
\hline & \multicolumn{2}{|c|}{ Yes } & \multicolumn{2}{|c|}{ No } & & & & \\
\hline & $\mathbf{n}$ & $\%$ & $\mathbf{n}$ & $\%$ & & $\begin{array}{l}\text { Lower } \\
\text { Limit }\end{array}$ & $\begin{array}{l}\text { Upper } \\
\text { Limit }\end{array}$ & \\
\hline \multicolumn{9}{|l|}{ Gender } \\
\hline Male & 10 & 28.6 & 25 & 71.4 & 3.48 & 1.26 & 9.11 & $<0.001$ \\
\hline Female & 17 & 10.3 & 148 & 89.7 & & & & \\
\hline \multicolumn{9}{|l|}{ History of genetic } \\
\hline Yes & 12 & 27.9 & 31 & 72.1 & 3.66 & 1.40 & 9.29 & $<0.001$ \\
\hline No & 15 & 9.6 & 142 & 90.4 & & & & \\
\hline \multicolumn{9}{|l|}{ Obese } \\
\hline Obese $\left(\mathrm{BMI} \geq 25 \mathrm{~kg} / \mathrm{m}^{2}\right)$ & 13 & 31.7 & 28 & 68.3 & 4.80 & 1.84 & 12.29 & $<0.001$ \\
\hline Normal $\left(\mathrm{BMI}<25.0 \mathrm{~kg} / \mathrm{m}^{2}\right)$ & 14 & 8.8 & 145 & 91.2 & & & & \\
\hline \multicolumn{9}{|l|}{ Diet } \\
\hline Good $(\geq 8)$ & 30 & 75.0 & 10 & 25.0 & 2.80 & 1.03 & 7.21 & $<0.001$ \\
\hline Poor $(<8)$ & 17 & 10.6 & 143 & 89.4 & & & & \\
\hline \multicolumn{9}{|l|}{ Sleeping duration } \\
\hline Lacking $(<8$ hours $)$ & 14 & 28.6 & 35 & 71.4 & 4.24 & 1.66 & 10.71 & $<0.001$ \\
\hline Enough ( $\geq 8$ hours) & 13 & 8.6 & 138 & 91.4 & & & & \\
\hline \multicolumn{9}{|l|}{ Stress Level } \\
\hline Stress (score $\geq 13$ ) & 9 & 39.1 & 14 & 60.9 & 5.67 & 1.86 & 16.36 & $<0.001$ \\
\hline Not stress (score < 13) & 18 & 10.2 & 159 & 89.8 & & & & \\
\hline \multicolumn{9}{|l|}{ Pocket money/month } \\
\hline Adequate $(<\mathrm{Rp} 350,000)$ & 18 & 10.9 & 147 & 89.1 & 2.82 & 0.99 & 7.47 & $<0.001$ \\
\hline $\operatorname{High}(\geq \operatorname{Rp} 350,000)$ & 9 & 25.7 & 26 & $74 \cdot 3$ & & & & \\
\hline
\end{tabular}

Table 3. The results of multilevel logistic regression analysis

\begin{tabular}{|c|c|c|c|c|}
\hline \multirow{2}{*}{ Independent Variable } & \multirow{2}{*}{ b } & \multicolumn{2}{|c|}{$95 \%$ CI } & \multirow[b]{2}{*}{$\mathbf{p}$} \\
\hline & & Lower Limit & Upper Limit & \\
\hline \multicolumn{5}{|l|}{ Fixed effect } \\
\hline Gender (male) & 1.87 & 0.38 & $3 \cdot 36$ & 0.014 \\
\hline With genetical history & 1.93 & 0.48 & $3 \cdot 39$ & 0.009 \\
\hline Obese $(\mathrm{BMI} \geq 25 \mathrm{~kg} / \mathrm{m} 2)$ & 2.15 & 0.76 & 3.55 & 0.002 \\
\hline Diet causing hypertension (score $\geq 8$ ) & 1.54 & 0.97 & 2.99 & 0.036 \\
\hline Lack of sleeping duration ( $<8$ hours) & 2.28 & 0.63 & 3.93 & 0.007 \\
\hline High stress level & 3.52 & 1.64 & $5 \cdot 39$ & $<0.001$ \\
\hline Pocket money per month ( $\geq$ Rp 350,000) & 2.00 & 0.45 & 3.56 & 0.011 \\
\hline \multicolumn{5}{|l|}{ Random effect } \\
\hline \multicolumn{5}{|l|}{$\mathrm{N}$ observation $=200$} \\
\hline \multicolumn{5}{|l|}{$\mathrm{N}$ group $=25$} \\
\hline \multicolumn{5}{|l|}{ Average group $=8, \min =8, \max =8$} \\
\hline \multicolumn{5}{|l|}{ Log likelihood $=-46.16 p=0.009$} \\
\hline $\mathrm{ICC}=22.47 \%$ & & & & \\
\hline
\end{tabular}


Journal of Epidemiology and Public Health (2019), 4(4): 259-269

https://doi.org/10.26911/jepublichealth.2019.04.04.01

\section{DISCUSSION \\ 1. The effect of gender on hyperten- sion in adolescents}

The results of this study indicated that gender had a close to significant effect on hypertension in adolescents aged 15-19 years $(\mathrm{b}=1.87 ; 95 \% \mathrm{CI}=0.38$ to $3.36 ; \mathrm{p}=$ 0.014). Adolescents with male gender increased the risk of hyper-tension higher by 1.87 units compared with adolescents with female gender.

This is in line with the study of Huang et al. (2011) stating that gender had an influence on the incidence of hypertension. Teenage boys tend to have a higher percentage than women (Yusrizal et al., 2017).

According to Everett and Zajacova (2015), there were differences in the percentage of hypertension based on gender in adolescents. The high percentage of hypertension in adolescent boys versus girls was in terms of biological factors, namely sex hormones, chromosomes, and other biological factors that could reduce hypertension in women (Everett and Zajacova, 2015).

2. The effect of family history of hypertension on hypertension in adolescents

The results of this study showed that genetic history had a close to significant effect on hypertension in adolescents aged 15-19 years $(b=1.93 ; 95 \% \mathrm{CI}=0.48$ to $3.39 ; \mathrm{p}=$ o.009). Adolescents who had a family history of hypertension had a higher risk of hypertension by 1.93 units compared to adolescents with adolescents who did not have a history of hypertension.

The results of this study are in line with Katulanda et al. (2015) stating that family history had a higher chance of parents being 1.28 times, grandmother / grandfather 1.34 times, and siblings 1.27 times (Katulanda et al., 2015). History of hypertension in adolescents had a higher prevalence than adolescents without a history of hypertension (Vedavathy and Sangamesh, 2016).

The results of this study are supported by Willig et al. (2010) if parents who experience hypertension, then teens will be higher at risk of developing hypertension. Genetic factors were believed to have a relationship with the incidence of hypertension, where if both parents, both father and mother suffer from hypertension, the chance of the disease being passed on to their offspring is 50\%, whereas if only one parent suffers from hypertension, then the chance of hereditary hypertension is 30\% (Willig et al., 2010).

\section{The effect of obesity on hyper- tension in adolescents}

The results of this study indicated that obesity had a significant effect on hypertension in adolescents aged $15-19$ years $(\mathrm{b}=$ $2.15 ; 95 \% \mathrm{CI}=0.76$ to $3.55 ; \mathrm{p}=0.002$ ). Obese adolescents increased the risk of hypertension higher by 2.15 units compared to adolescents who were not obese.

Hypertension in adolescents was affected by obesity. Obesity caused blood pressure to increase because large body mass increases the amount of blood needed to circulate food and oxygen to all body tissues (Benmohammed et al., 2011; Forouzanfar et al., 2016).

Obesity and overweight were known as risk factors for increased blood pressure, specific cardiovascular disease, high blood pressure and all causes of cardiovascular disease in all age groups including adolescents (Bucher, 2013).

\section{The effect of dietary pattern on hypertension in adolescents}

The results of this study indicated that the diet had a significant effect on hypertension in adolescents aged 15-19 years $(b=1.54$; $95 \% \mathrm{CI}=0.97$ to $2.99 ; \mathrm{p}=0.036)$. Teenagers who did not maintain a dietary pattern increase the risk of hypertension higher by 
1.54 units compared to teens who maintain their dietary patterns.

Malhotra and Nistane (2016) stated that diet is very influential on the incidence of hypertension in adolescents. One of the habits in adolescents is eating high-energy junk food and fast food, containing lots of fat that can cause obesity (Malhotra and Nistane, 2016).

A high-quality diet in adolescence, as measured by taking AHEI during high school, is associated with a lower risk of developing risk factors for hypertension during mid-adulthood. The Mediterranean diet in adolescents is at a lower risk of developing the metabolic syndrome in adulthood. A healthy diet early in life (during adolescence) can also play an important role in preventing the occurrence of hypertension (Dahm, 2016; Ewald and Haldeman, 2016).

\section{The effect of sleep duration on hypertension in adolescents}

The results of this study showed that sleep duration had a near-significant effect on hypertension in adolescents aged 15-19 years $(b=2.28$; 95\% $\mathrm{CI}=0.63$ to 3.93 ; $\mathrm{p}=$ 0.007). Adolescents with a lack sleeping duration increased their risk of hypertension higher by 2.28 units compared to adolescents with sufficient sleep duration.

The results of this study are supported by Istyanto (2019) that adolescents with lacking sleep quality had the possibility of 0.15 times having hypertension compared to those who had a good sleeping quality (Istyanto et al., 2019). According to Bansil et al. (2011) adolescents with less sleep duration 1.84 times experience hypertension compared to adolescents whose sleep duration is sufficient. There were several elements of lifestyle that affected blood pressure, but not directly. One factor that can affect blood pressure is a sleep disorder (Bansil et al., 2011).
Sleeping duration could increase the blood pressure and heart rate. Chronic sleep deprivation could increase blood pressure by an average of 24 hours and cause structural adaptations that include the cardiovascular system to operate in balance with high blood pressure and increase the risk of hypertension (Gangwisch, 2014).

\section{The effect of stress on hyperten- sion in adolescents}

The results of this study indicated that stress had a significant effect on hypertension in adolescents aged $15-19$ years $(b=$ $3.52 ; 95 \% \mathrm{CI}=1.64$ to $5.39 ; \mathrm{p}<0.001)$. Teens who had high stress levels had a higher risk of developing hypertension by 3.52 units compared to adolescents with low stress levels.

This is in line with the study of Mittal and Singh (2010) which states that adolescents with high stress levels are more susceptible to hypertension. The level of teenage stressors is higher. Development and psychology of immature adolescents will be easily affected by the surrounding environment (Mittal and Singh, 2010).

Stress could occur if someone was in a tense condition, feeling depressed, sad, scared and feeling guilty. This condition would stimulate the kidneys to produce adrenal hormones which will stimulate the heart to pump blood faster and stronger so that blood pressure increases. If this condition lasts for a long time and does not immediately get treatment it can cause hypertension (Koutsaki et al. 2017; Abeetha et al. 2018).

\section{The effect of money pocket on hypertension in adolescents}

The results of this study indicated that the economic level had a significant effect on hypertension in adolescents aged 15-19 years $(b=2.00 ; 95 \% \mathrm{CI}=0.45$ to $3.56 ; \mathrm{p}=$ o.011). Teenagers with high allowances 
Journal of Epidemiology and Public Health (2019), 4(4): 259-269

https://doi.org/10.26911/jepublichealth.2019.04.04.01

increased the risk of hypertension nearing 2.00 units compared to teenagers enough pocket money.

The results of this study are in line with Tareque et al. (2015), hypertension is more vulnerable in adolescents with high economies. Teenagers with high economies can make teenagers have an unhealthy diet and lifestyle. Teenagers with more money can use money to buy expensive and unhealthy foods, like buying junk food and fast food (Tareque et al. 2015).

Mills et al. (2016) stated that economic levels greatly influence the incidence of hypertension. Economic levels will influence diet and lifestyle (Mills et al. 2016). Economic levels can provide changes in eating habits, so it is necessary to educate children and parents about the value of a healthy and balanced diet (Florou and Chania, 2017).

\section{The effect of school on hyperten- sion in adolescents}

The results showed that the contextual influence on the school level on hypertension in adolescents aged 15-19 years $(\mathrm{ICC}=22.47 \%)$. Variations in hypertension in adolescents aged 15-19 years amounting to $22.47 \%$ are influenced by school. The ICC value in this study was greater than the benchmark rule of thumb $8 \%-10 \%$, then the school's contextual influence in this study was very important to note.

Social factors that could influence hypertension in adolescents were economic background, and the surrounding environment. The surrounding environment included conditions that affect the hypertension or contextual factors of adolescent schools (Fitriani, 2012).

Based on the results of the study it can be concluded that there was a significant influence between economic level, genetic history, gender, obesity, diet, sleep duration, and stress level on hypertension in adolescents aged 15-19 years. Variations at the school level indicated that there was a contextual influence on hypertension in adolescents aged $15-19$ years.

\section{AUTHORS CONTRIBUTION}

Mayasari Kurnianingsih, the main author's roles were collecting and processing data analysis; Yulia Lanti Retno Dewi, examined the conceptual framework and methodology; Eti Poncorini Pamungkasari, reviewed the paper.

FUNDING AND SPONSORSHIP

This study was self-funded.

CONFLICT OF INTEREST

There was no conflict of interest.

\section{ACKNOWLEDGEMENT}

We would like to thank the school for helping with the study and participating students who were willing to become the respondents.

\section{REFERENCE}

Abeetha S, Sureka V, Brinda S, Ganesh M, Olickal JJ, Sujatha (2018). Prevalence of prehypertension and its association with levels of stres and anxiety among students of various disciplines in Chennai - a cross-sectional study. National Journal of Physiology, Pharmacy and Pharmacology, 8(12): 15991604. doi: 10.5455/njppp.2008.8.0928210092018.

Aglony M, Acevedo M, Ambrosio, G (2009). Hypertension in adolescents. Expert Review of Cardiovascular Therapy, 7(12): 1595603.doi:10.1586/erc.09.150. Arisman MB (2009). Buku ajar ilmu gizi gizi dalam daur kehidupan, di buku ajar ilmu gizi gizi dalam daur kehidupan (Nutrition science text- 
books in the life cycle). Retrived from: http://www.digilib.unipdu.ac.id/beranda/index.php?p=show_detail\&id= 4940

Health Research and Development Agency of the Indonesian Ministry of Health (2013). Riset kesehatan dasar 2013 (2013 basic health research). Kementrian Kesehatan Republik Indonesia. Retrived from: www.depkes.go.id

Bansil P, Kuklina EV, Merritt RK, Yoon PW (2011). Associations between sleep disorders, sleep duration, quality of sleep, and hypertension: results from the national health and nutrition examination survey, 2005 to 2008. Journal of Clinical Hypertension, 13(10): 739-43. doi: 10.1111/j.1751-7176.2011.00500.x.

Benmohammed K, Nguyen MT, Khensal S (2011). Arterial hypertension in overweight and obese algerian adolescents: role of abdominal adiposity, diabetes, and metabolism. Medicine National Institute of Health, 37(4): 291-7. doi: 10.1016/j.diabet.2010.10.010.

Bucher, Ferrarini A, Weber N, Bullo M, Bianchetti MG, SG (2013). Primary hypertension in childhood. Medicine National Institute of Health, 15(5): 444-52. doi: 10.1007/s1190601303788.

Dahm CC, Chomistek AK, Jakobsen MU, Mukamal KJ, Eliassen AH, Sesso HD, Overvad K, Willett WC, Rimm EBCS (2016). Adolescent diet quality and cardiovascular disease risk factors and incident cardiovascular disease in middle-aged women. Medicine National Institute of Health, 5(12). doi: 10.1161/JAHA.116.003583.

Everett B, Zajacova A (2015). Gender differences in hypertension and hypertension awareness among young adults.
Biodemography and Social Biology, 61(1): 1-17. doi: 10.1080/19485565.2014.929488.

Ewald DR, Haldeman LA (2016). Risk factors in adolescent hypertension global pediatric health. Medicine National Institute of Health, 16(3). doi: 10.1177/2333794x15625159.

Fitriani A (2012). Kondisi sosial ekonomi dan stres pada wanita hipertensi anggota Majelis Taklim. Kesmas: National Public Health Journal, 7(5). doi: 10.21109/kesmas.v7i5.43.

Forouzanfar MH (2016). Global regional and national comparative risk assessment of 79 behavioural, environmental and occupational, and metabolic risks or clusters of risks, 1990-2015: a systematic analysis for the global burden of disease study 2015. Medicine National Institute of Health, 35(1). doi: 10.1016/So140-6736(16)31679-8.

Florou X, Chania M (2017). The impact of the economic crisis on hypertension in children. Journal of Hypertension, 35(1). doi: 10.1097/01.hjh.0000523459.89922.e3.

Gangwisch JE (2014). A review of evidence for the link between sleep duration and hypertension. American Journal of Hypertension, 27(10): 1235-42. doi: 10.1093/ajh/hpuo71.

Huang, Hui Ting et al. (2016). Structural factors affecting health examination behavioral intention. International Journal of Environmental Research and Public Health, 13(4): 395. doi: 10.3390/ijerph13040395.

Istyanto F, Mudigdo A, Rahardjo SS (2019). Path analysis on the biopsychosocial factors associated with hypertension. Journal of Epidemiology and Public Health, 4(2): 70-80. doi: 10.26911/jepublichealth.2019.04.02.0. 
Katulanda P, Ranasinghe P, Cooray DN, Jayawardena R (2015). The influence of family history of diabetes on disease prevalence and associated metabolic risk factors among Sri Lankan adults. Diabetic Medicine, 5(576). doi: 10.1111/dme.12591.

Loh KW Rani F, Chan TC, Loh HY, Ng CW, Moy FM (2013). The association between risk factors and hypertension in Perak, Malaysia. Medical Journal of Malaysia, 68(4): 291-6. Retrived from: https://www.ncbi.nlm.nih.gov/pubmed/24145254

Koutsaki M, Kallistratos MS, Soulioti E, Kouremenos N, Vergis K, Koukouzeli A, Diakoumakou O, Mascha O, Mela A, Manolis AJ (2017). Influence of stress and anxiety on blood pressure levels in patients undergoing orthopedic surgery. Journal of Hypertension, 35(1): e168-e168. doi: 10.1097/o1.hjh.00o0523638.50614.co

Malhotra K, Nistane R (2016). Study of obesity and hypertension in adolescents and their relationship with anthropometric indices. International Journal of Contemporary Pediatrics, 3(3) doi: 10.18203/2349-3291.ijcp20162383.

Manimunda SP, Sugunan AP, Benegal V, Balakrisna N, Rao MV, Pesala KS (2011). Association of hypertension with risk factors \& hypertension related behaviour among the aboriginal nicobarese tribe living in car Nicobar Island, India. Indian Journal of Medical Research, 133(3). Retrived from: https://www.ncbi.nlm.nih.gov/pmc/articles/PMC3103153/

Mills KT KT, Bundy JD, Kelly TN, Reed JE, Kearney PM, Reynolds K, Chen J, He $J$ (2016). Global disparities of hypertension prevalence and control: a systematic analysis of population-based studies from 90 countries. Medicine National Institute of Health, 134(6): 441-50. doi: 10.1161/CIRCULATIONAHA.115.018912.

Mittal BV, Singh AK (2010). Hypertension in the developing world: challenges and opportunities. American Journal of Kidney Diseases, 55(3): 5908. doi: 10.1053/j.ajkd.2009.06.044.

Puspita RC, Tamtomo D, Indarto D (2017). Health belief model for the analysis of factors affecting hypertension preventive behavior among adolescents in Surakarta. Journal of Health Promotion and Behavior, 2(2): 183-196. doi: 10.26911/thejhpb.2017.02.02.08.

Tareque I, Koshio A, Tiedt AD, Hasegawa T (2015). Are the rates of hypertension and diabetes higher in people from lower socioeconomic status in Bangladesh. Results from a Nationally Representative Survey, 10(5): e0127954. doi: 10.1371/journal.pone.0127954.

Vedavathy, Sangamesh S (2016). Prevalence of hypertension in urban school going adolescents of Bangalore, India. International Journal of Contemporary Pediatrics, 3(2): 416-423 doi: 10.18203/23493291.ijcp20160488.

Willig AL, Casazza K, Dulin KA, Franklin FA, Amaya M, Fernandes JR (2010). Adjusting adiposity and body weight measurements for heightalters the relationship with blood pressure in children. American Journal Hypertension, 23(8): 904-910. doi: https://doi.org/10.1038/ajh.2010.82

World Health Organization (2013). World health statistics 2013. World health statistic report.

Yanes, Licy L, Jane F, Reckelhoff (2011). Postmenopausal hypertension. American Journal of Hypertension, 24(7): 740-749. doi: https://doi.org/10.1038/ajh.2011.71. 
Yogyakarta, DKDI (2017). Profil kesehatan Daerah Istimewa Yogyakarta 2017 (Health profile of Yogyakarta Special Region 2017). Retrived from: www.depkes.go.id

Yusrizal Mirza, Indarto D, Akhyar M (2017). Risk of hypertension in adolescents with over nutritional status in Pangkalpinang, Indonesia. Multilevel analysis on the biopsychosocial and environment factors affecting the risk of pneumonia in infants. Journal of Epidemiology and Public Health, 1(1): 27-36. doi: https://doi.org/jepublichealth.2016.01.01.06. 